\title{
Citizen science recording the shifting distribution of subtropical species in the Southwestern Atlantic: the southernmost records of Orthopristis ruber (Haemulidae, Lutjaniformes)
}

\author{
MARTÍN LAPORTA ${ }^{1,2^{*}}$, GRACIELA FABIANO ${ }^{1,3}$, FABRIZIO SCARABINO ${ }^{4,5}$, ALFONSO \\ PEREYRA $^{4}$, SANTIAGO SilveirA $^{1,3}$, IRENE MACHADO ${ }^{4}$ \& PATRICIA CORREA ${ }^{4}$ \\ ${ }^{1}$ Dirección Nacional de Recursos Acuáticos, Ministerio de Ganadería, Agricultura y Pesca, Rambla \\ Portuaria, s/n, La Paloma, CP 27001, Rocha, Uruguay. \\ ${ }^{2}$ Campus DoMar, International Campus of Excellence, University of Santiago de Compostela, A Coruña \\ 15782, Spain \\ ${ }^{3}$ Unidad de Patología, Biología y Cultivo de Organismos Acuáticos, Facultad de Veterinaria, Universidad \\ de la República. Rambla Portuaria, s/n, La Paloma, CP 27001, Rocha, Uruguay \\ ${ }^{4}$ Centro Universitario Regional de Este, Sede Rocha, Universidad de la República. Ruta 9 intersección Ruta \\ 15, CP 27000, Rocha, Uruguay \\ ${ }^{5}$ Museo Nacional de Historia Natural, Ministerio de Educación y Cultura. Miguelete 1825, CP 11800, \\ Montevideo, Uruguay.
}

*Corresponding author: negrolapo@gmail.com

\begin{abstract}
In recent times, citizen science has proved to be a major contribution in the study of rare fish species and marine diversity. Since 1997, there has been an increase in the amount of sea surface temperature anomalies (SSTA) in the Uruguayan coast, and in the last 10 years these have been more intense, with longer duration and higher values. Here we report the first records of the Corocoro grunt Orthopristis ruber in the Uruguayan coast ( $\left.34^{\circ} 54^{\prime} \mathrm{S}\right)$, extending its range circa $700 \mathrm{~km}$ south of the previously reported southern limit in Brazil $\left(18^{\circ} \mathrm{S}\right.$ to $\left.31^{\circ} \mathrm{S}\right)$. Eight records, coming from recreational and artisanal catches obtained in 2018-2020, were compiled using social networks. Two fishes were collected and preserved as voucher specimens. Several features of the records suggest that these are not occasional and that the distributional range of this species is truly expanding to higher latitudes, namely: 1) the occurrence of juveniles and adults in Uruguayan waters; 2) the number of records compiled; 3) the consecutive years of the records; 4) the testimony of several Uruguayan anglers indicating that they had already fished this species in previous years; and 5) a global scenario of ocean warming with positive sea surface temperature anomalies.
\end{abstract}

Key words: monitoring; recreational fishing; ocean warming; Corocoro grunt; Uruguay.

Resumen: Registro de cambios en la distribución de especies subtropicales en el Atlántico Sudoccidental mediante ciencia ciudadana: el registro más austral de Orthopristis ruber (Haemulidae, Lutjaniformes). Recientemente la ciencia ciudadana ha demostrado una contribución muy importante al estudio de las especies raras de peces y de la diversidad marina. Desde 1997, ha habido un aumento en la cantidad de anomalías positivas de la temperatura superficial del mar (TSM) en la costa uruguaya, y en los últimos 10 años éstas han sido más intensas, con mayor duración y valores más altos. Aquí reportamos los primeros registros del Corocoro Orthopristis ruber en Uruguay ( $\left.34^{\circ} 54^{\prime} \mathrm{S}\right)$, extendiendo su distribución $700 \mathrm{~km}$ al sur del rango previamente reportado en Brasil $\left(18^{\circ} \mathrm{S}\right.$ a $\left.31^{\circ} \mathrm{S}\right)$. Se recopilaron ocho registros, procedentes de capturas recreativas y artesanales entre 2018-2020, utilizando las redes sociales. Se recolectaron dos ejemplares que se conservaron como especímenes vouchers. Varias 
características de los registros sugieren que éstos no son ocasionales y que el rango de distribución de esta especie se está expandiendo a latitudes más altas: 1) la ocurrencia de juveniles y adultos en aguas uruguayas; 2) el número de registros recopilados; 3) los años consecutivos de los registros; 4) el testimonio de varios pescadores uruguayos indicando que ya habían pescado esta especie en años anteriores; y 5) un escenario global de calentamiento del océano con anomalías positivas de la TSM.

Palabras clave: monitoreo; pesca recreativa; calentamiento del océano, Corocoro; Uruguay.

\section{Introduction}

The marine bony fish diversity of Uruguay lacks recent in-depth revisions, and the greatest research efforts date back to the past century (see e. g. Devincenzi 1926, Menni et al. 1984). A recent effort (Nion et al. 2016) to compile the recorded species for Uruguayan waters fails to relate the species to past literature or unpublished records, indicating a great challenge to be developed in this regard. Furthermore, the history and development of ichthyological collections has been difficult in the country, hindering ichthyological research (Loureiro et al. 2016). Therefore, new efforts are being carried out through interinstitutional and transdisciplinary approaches, especially considering the biogeographical context of the Uruguayan waters (Laporta et al. 2018). In this context, citizen science constitutes a powerful and cost-effective method for the detection and monitoring of rare native and nonnative fish species (Tiralongo et al. 2020). In fact, data collected from these activities by the participants were often easily verifiable and can be considered as equally reliable to those collected by scientists, as already highlighted in appropriate literature (Lewandowski \& Specht 2015).

Climate change may affect the life cycle seasonality, and distribution of marine species (Poloczanska et al. 2013, 2016). Isotherms at the ocean surface have migrated at comparable or faster rates than isotherms over land during the past 50 years (1960-2009) (Burrows et al. 2011). Thus, a higher rate of ocean warming could affect the distribution, abundance, and life history traits of fishes (Pauly \& Cheung 2018).

During the past three decades, there has been a systematic increase in sea surface temperature (SST) over the Southwestern Atlantic Ocean (Ortega et al. 2012). At the same time, since 1997 there has been an increase in the amount of positive sea surface temperature anomalies (SSTA) in the Uruguayan coast, and in the last 10 years these have been more intense, with longer duration and higher values (Ortega et al., 2016; Martínez et al., 2017, Manta et al. 2018, Gianelli et al. 2019, Franco et al.
2020). These facts have implied the occurrence of marine species of different taxa with tropical and subtropical distribution, associated to an extended presence of warm subtropical water derived from the Brazilian Current along the Uruguayan continental shelf (Leoni et al. 2016, Martínez et al. 2017, De Wysiecki et al. 2018, Pereyra et al. 2019).

The Corocoro grunt Orthopristis ruber (Cuvier, 1830) (Haemulidae, Lutjaniformes) is one of the seven valid species of the genus as reviewed and redefined based on the analysis of color patterns and meristic data, as well as DNA barcoding by Marceniuk et al. (2019). These authors restricted its distribution to Brazil, from Espírito Santo $\left(18^{\circ} \mathrm{S}\right)$ state to Rio Grande do Sul ( $\left.31^{\circ} \mathrm{S}\right)$ and indicated that this species is abundant in estuarine and coastal waters over several bottom types, up to $70 \mathrm{~m}$ depth.

The present study reports the first records of Orthopristis ruber in Uruguayan waters by using citizen science and it extends its previously known distribution range.

\section{Materials and methods}

Study area: This study is focused on the Uruguayan Atlantic coast in the Southwestern Atlantic Ocean (SWAO) shelf (Fig. 1). The SWAO shelf extends from Cabo Frio ( $22^{\circ} \mathrm{S}$, Brazil) to the tip of Tierra del Fuego (55 S, Argentina) (Franco et al. 2020). The continental shelf in the study region is oceanographically complex, characterized by seasonal variations modulated by the confluence of two water masses with different thermohaline characteristics (Piola et al. 2018). This confluence is marked by a complex array of strongly contrasting water types (Gordon 1989). Subtropical warm waters are carried southward by the Brazil Current along the shelf, while Subantarctic cold waters are transported northwards by the Malvinas Current (Scarabino et al. 2016, Franco et al. 2018).

Records of the Corocoro grunt along the Uruguayan coast were obtained from the marine recreational fisheries pilot monitoring program carried out by the National Directory of Aquatic Resources (ICES 2020). This started in 2015 with 


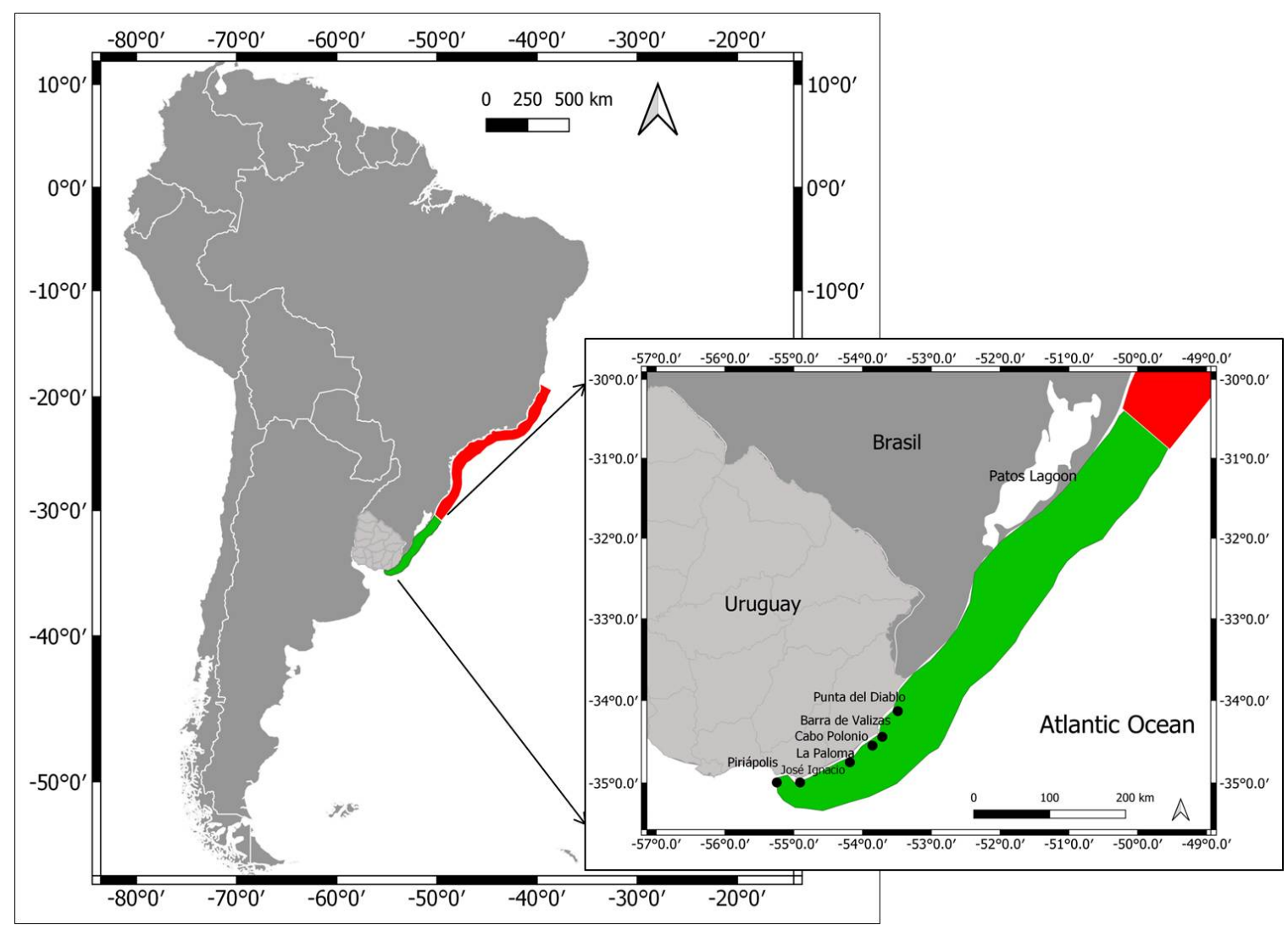

Figure 1. Previously known geographic marine range of Orthopristis ruber (red area: $18^{\circ} \mathrm{S}-31^{\circ} \mathrm{S}$ ) in Marceniuk et al. (2019) and the extended range (green area) with the locations on the Uruguayan coast where the records were reported in the Southwestern Atlantic Ocean.

the main goal of collecting data on the catches and providing a baseline for the management and regulation of these fisheries. It is a participatory program, where fishers and spearfishers contribute information about their catches voluntarily. Data sources came from catches, biological samplings, personal contacts between scientists and fishers, and from publications in social media made by the fishers. Data collected were date, fishing zone and modality, fisher's name, specimen photographs, total length, and weight (when it was possible). The specimens were identified using the key proposed by Marceniuk et al. (2019). Whenever possible, the captured fishes were secured and used to confirm the identity, and later preserved and deposited as voucher specimens in the Ichthyological collection of the Museo Nacional de Historia Natural, Montevideo (MNHN).

\section{Results and discussion}

Eight records of $O$. ruber were obtained from March 2018 to October 2020 along the Uruguayan coast. All of them come from six coastal localities with rocky outcrops and sandy beaches (Table I; Fig. 1). Six of these records were caught by recreational anglers, other by a recreational spearfisher, mentioning that at the time of their capture there were two fishes inside a cave, and he could only shoot one of them, and that they emitted a sound similar to the snoring of the white-mouth croaker Micropogonias furnieri. The remaining record was obtained from an artisanal fishery boat (Table I).

In two of these records, it was possible to collect and preserve the specimens in the MNHN ichthyological collection (MHNM 4199; MHNM 4200). For these two specimens, most meristic characters and other diagnostic features agreed with those indicated by Marceniuk et al. (2019) (Table II).

The two specimens collected, as well as other five for which only photographs are available, also matched the coloration pattern described by Marceniuk et al. (2019) for living specimens, i.e., body with very conspicuous vertical bars, large and conspicuous black humeral spot above pectoral fin base, and small black spot on rear border of operculum (Fig. 2). Additionally, once fixed the collected specimens coincided with the preserved coloration pattern described by these authors, i.e., light brown, lighter ventrally, with dark spot on rear 
Table I. Records of Corocoro Orthopristis ruber obtained along the Uruguayan coast: TL= total length; ${ }^{\mathrm{t}}=$ estimated by size reference in picture; Fig.2= letter of photo in Figure 2. Localities: BV: Barra de Valizas; LP: La Paloma; PD: Punta del Diablo; CP: Cabo Polonio; Ps: Piriápolis; JI: José Ignacio.

\begin{tabular}{|c|c|c|c|c|c|c|}
\hline Date & Locality & Coordinates & Media & Gear & Other data & Fig. 2 \\
\hline 27-03-2018 & BV & $34^{\circ} 20^{\prime} \mathrm{S}-53^{\circ} 46^{\prime} \mathrm{W}$ & WhatsApp Inc ${ }^{\circledR}$ & Boat angling & TL $21 \mathrm{~cm}^{\dagger}$ & A \\
\hline 30-04-2018 & LP & $34^{\circ} 40^{\prime} \mathrm{S}-54^{\circ} 09^{\prime} \mathrm{W}$ & WhatsApp Inc® & Coastal angling & TL $29 \mathrm{~cm}^{\dagger}$ & B \\
\hline 24-02-2019 & $\mathrm{PD}$ & $34^{\circ} 02^{\prime} \mathrm{S}-53^{\circ} 32^{\prime} \mathrm{W}$ & WhatsApp Inc® & Coastal angling & TL $13 \mathrm{~cm}^{\mathrm{t}}$ & $\mathrm{C}$ \\
\hline 12-05-2019 & $\mathrm{CP}$ & $34^{\circ} 24^{\prime} \mathrm{S}-53^{\circ} 47^{\prime} \mathrm{W}$ & WhatsApp Inc ${ }^{\circledR}$ & Coastal angling & TL $18 \mathrm{~cm}^{\dagger}$ & \\
\hline 19-052019 & $\mathrm{CP}$ & $34^{\circ} 24^{\prime} \mathrm{S}-53^{\circ} 47^{\prime} \mathrm{W}$ & Sampling & Coastal angling & $\begin{array}{c}\text { MHNM-4199 } \\
\text { (TL: } 18 \mathrm{~cm} ; \mathrm{W}: 95 \mathrm{~g})\end{array}$ & $D-F$ \\
\hline 18-01-2020 & Ps & $34^{\circ} 54^{\prime} \mathrm{S}-55^{\circ} 15^{\prime} \mathrm{W}$ & Facebook $^{\mathrm{TM}}$ & Artisanal gillnet & $\begin{array}{c}\text { TL } 28 \mathrm{~cm}^{\dagger} \\
\text { (Southermost record) }\end{array}$ & G \\
\hline 25-04-2020 & $\mathrm{BV}$ & $34^{\circ} 20^{\prime} \mathrm{S}-53^{\circ} 46^{\prime} \mathrm{W}$ & Sampling & Coastal angling & $\begin{array}{c}\text { MHNM-4200 } \\
\text { (TL: } 13 \text { cm; W: } 32 \text { g) }\end{array}$ & $\mathrm{E}$ \\
\hline $10-10-2020$ & JI & $34^{\circ} 50^{\prime} \mathrm{S}-54^{\circ} 37^{\prime} \mathrm{W}$ & WhatsApp Inc ${ }^{\circledR}$ & Spearfishing & TL $28 \mathrm{~cm}^{\dagger}$ & $\mathrm{H}$ \\
\hline
\end{tabular}

Table II. Meristic characteristics of the collected Orthopristis ruber specimens compared with those indicated by Marceniuk et al. (2019) for the diagnosis of the species.

\begin{tabular}{|c|c|c|c|}
\hline \multirow[b]{2}{*}{ Diagnostic character } & \multicolumn{2}{|c|}{ Specimen } & \multirow{2}{*}{$\begin{array}{l}\text { Diagnosis by } \\
\text { Marceniuk } \\
\text { et al. (2019) }\end{array}$} \\
\hline & MHNM-4199 & MHNM-4200 & \\
\hline Dorsal-fin rays & XII / 15 & XII / 15 & XII / 14-15 \\
\hline Anal-fin rays & $\mathrm{III} / 10$ & III / 10 & $\mathrm{III} / 10$ \\
\hline Pectoral-fin rays & 17 & 17 & $17-18$ \\
\hline Pelvic-fin rays & $\mathrm{I} / 5$ & $\mathrm{I} / 5$ & $\mathrm{I} / \mathrm{5}$ \\
\hline Principal caudal-fin rays & $9+8=16$ & $9+8=17$ & $9+8=17$ \\
\hline Lateral-line scales & 57 & 55 & $52-57$ \\
\hline $\begin{array}{l}\text { Scales above lateral line to base of first } \\
\text { dorsal-fin spine }\end{array}$ & 10 & 10 & $10-13$ \\
\hline Scales below lateral line to first anal-fin spine & 15 & 16 & $15-17$ \\
\hline $\begin{array}{l}\text { Opercle lacking exposed spine, covered with 6-7 } \\
\text { vertical rows of ctenoid scales }\end{array}$ & 6 & 6 & $6-7$ \\
\hline
\end{tabular}

border of scales, forming irregularly oblique dark brown lines on the flanks; dark brown spots on operculum and below eyes; small, marked black spot on rear border of operculum and a conspicuous black humeral spot above pectoral-fin base; trunk with six dark faded irregular vertical bars, their width nearly equal to eye length; dorsal and anal fins hyaline, with dark brown line along the base of the hyaline pectoral and pelvic fins, and caudal fin dusky, darker in middle rays (Fig. 2. F).
A specimen recorded on May 12, 2019 had its guts and head removed by the fisher who caught it before the photograph was taken. However, the specimen was identified as $O$. ruber through the analysis of the photo, since the color patterns described previously were the same in this specimen. In addition, the same fisher reported a subsequent record a week later (MHNM 4199); his testimony explaining that it was the same fish helped to validate the identification of the previous individual. 

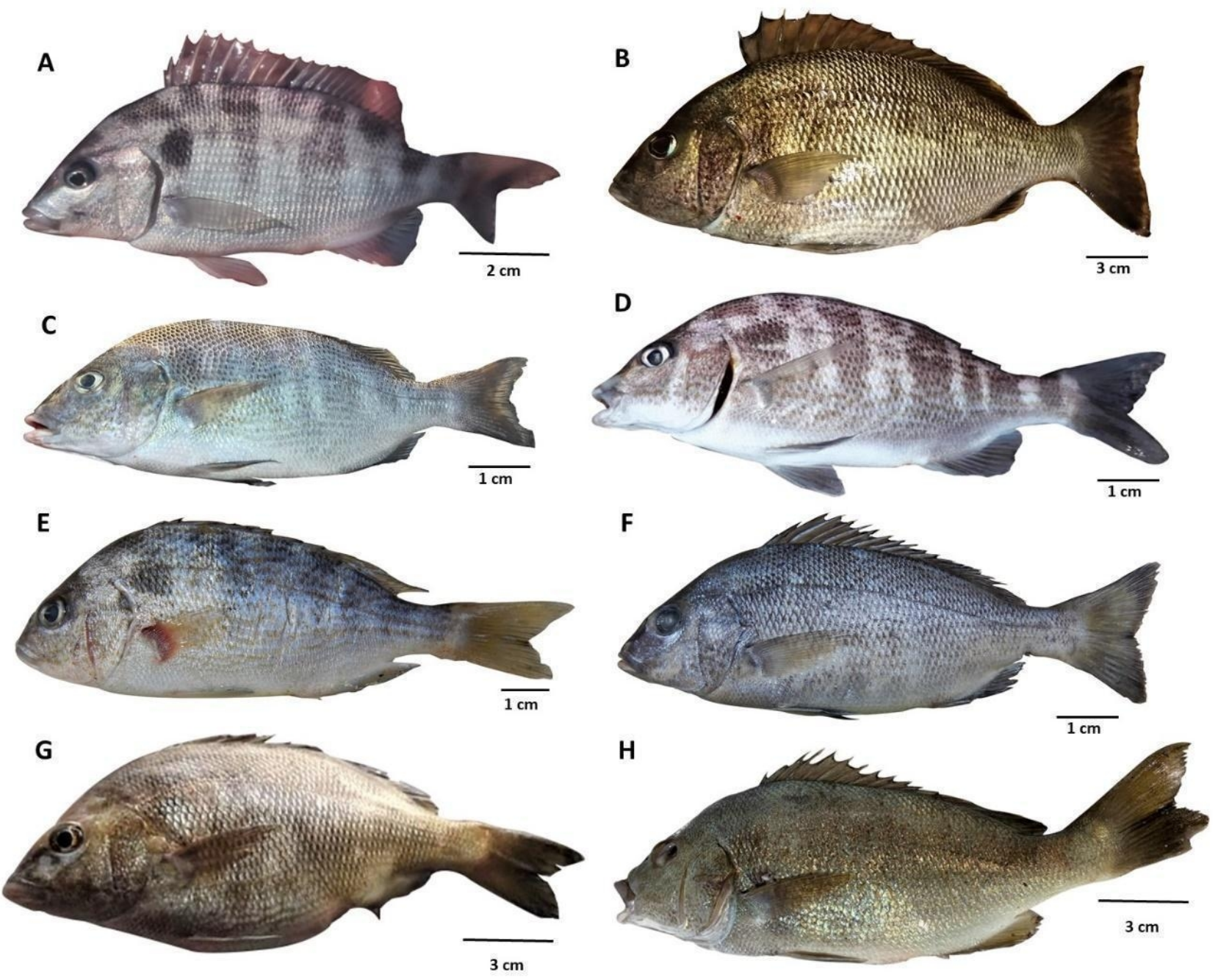

Figure 2. Photographies of recently obtained specimens of Orthopristis ruber registered along six coastal localities in Uruguay. A-B-C. Registered by anglers. D-E. Registered by anglers, sampled, collected and preserved (D= MHNM4199 - E= MHNM-4200). F. Fixed specimen D= MHNM-4199, after being preserved in formalin 10\%. G. Registered by artisanal fisher, southernmost record. H. Registered by spearfisher.

The three largest Orthopristis ruber specimens, with about 28 and $29 \mathrm{~cm}$ total length (Figure 2. B-G-H), are considered adults according to the size at first maturity (Lm50) estimated by Vianna and Veranni (2002). In the photographs of these specimens, it is not possible to observe the very conspicuous vertical bars neither the large and the conspicuous black humeral spot above pectoral fin base; Marceniuk et al. (2019) indicated that "Dark bars fade soon after death", however two other specific diagnostic features can be observed: the diffuse small black spot on the rear border of the operculum and the punctuations or small rounded brown-orange spots in the upper half of the body.
All the records of $O$. ruber in Uruguayan coastal waters here reported were obtained in months and years with positive sea surface temperature anomalies (SSTA) registered for the Southwestern Atlantic region (NOAA 2020a,b,c,d,e,f). This implies an extended presence of the warm subtropical waters in the Uruguayan Atlantic coast and could explain the occurrence of this tropical and subtropical species in these temperate latitudes.

The previously southernmost published record for $O$. ruber has been recently indicated by Marceniuk et al. (2019) based on specimens collected in the Brazilian coast of Rio Grande do Sul 
(MZUSP 68079, 4: 133-174 mm SL, 3063’s, $\left.49^{\circ} 81^{\prime} \mathrm{W}\right)$. However, this species was also cited for the Patos Lagoon, RS, Brazil by Vieira et al. (2018) and Possamai et al. (2018) in their species list, but without further data. Possamai (pers. comm. $^{1}$ ) indicated that their record is based on fishes caught by beach seine in May $2000(n=4)$ and in July 2006 $(\mathrm{n}=1)$, both at the same site (Praia dos Franceses: $32^{\circ} 03$ '38.9 "S and 52 $02^{\circ} 16.3$ "W), during a longterm monitoring programme (https://peld.furg.br/).

Our results expand southward the marine range distribution of Orthopristis ruber reported in Marceniuk et al. (2019) from $30^{\circ} 63$ 'S to $34^{\circ} 54^{\prime} \mathrm{S}$ ( $700 \mathrm{~km})$. Several features of the records and their context suggest that the Uruguayan records are not occasional and that the marine distributional range of this species is truly expanding to higher latitudes, namely: 1) the simultaneous occurrence of juveniles (two specimens) and adults (six specimens) in Uruguayan waters; 2) the amount of records compiled in this study (eight specimens); 3) the consecutive years of these records (2018 to 2020); 4) the testimony of several Uruguayan anglers indicating that they had already fished the species in previous years; 5) the extension of its distribution along the Uruguayan coast $(150 \mathrm{~km}) ; 6)$ the proximity to Patos Lagoon records published by Vieira et al. (2018) and Possamai et al. (2018) to the northeastern-most site where it was recorded in Uruguay ( $250 \mathrm{~km}) ; 7$ ) the time elapsed between the recording of Patos Lagoon in 2006 and the recent recording in Uruguay in 2020 (fourteen years); 8) a global scenario of ocean warming with high intensity of positive sea surface temperature anomalies in the last 10 years (Ortega et al. 2016; Martínez et al. 2017).

The joint work carried out between fishers and researchers reveals the importance of the contribution of citizen science in providing knowledge about the distribution of rare fish species and marine diversity in general (Irigoyen et al. 2005, Lehtiniemi et al. 2020, Pita et al. 2018, 2020, Tiralongo et al. 2020). Together, social networks and mobile applications are proving to be fundamental tools for reporting and estimating catches from recreational fisheries, which would otherwise be almost inaccessible (Venturelli et al. 2016). In countries such as Uruguay, where governmental resources are often scarce for developing marine research applied to strengthening fisheries

1 Bianca Possamai, Laboratório de Ictiologia - Instituto de Oceanografia, Universidade Federal do Rio Grande - FURG. Av. Itália km 8 s/n - Rio Grande RS management, this type of approach, together with participatory monitoring programs, become even more relevant and help building baseline knowledge towards improving its regulations.

\section{Conclusions}

The records here reported are the first for Uruguayan waters and expand the marine range distribution of Orthopristis ruber from that previously reported in Brazil to nearby $700 \mathrm{~km}$ to the South in Uruguay.

Some particularities of our results suggest that the Uruguayan records are not occasional and that the marine distributional range of this species is truly expanding to higher latitudes, mainly due a global scenario of ocean warming with high intensity of positive sea surface temperature anomalies in the last 10 years in the SWAO shelf. The involvement of citizen science was essential in compiling all records of Orthopristis ruber presented in this study.

\section{Acknowledgements}

To the fishers Diego Torrens, Fredy Calimares "Perico", Juan and Robert Acosta, Alberto Acosta, Omar Bentancur "Negro Cachito", Andrés Rodríguez and Daniel Chan for collecting the specimens or sending the photos. To Nicolas Bailly for his help in the identification of one specimen. To Bianca Possamai and Alexandre Garcia for sending the additional data of the records in Patos Lagoon (RG, Brazil). We also acknowledge Wilson S. Serra for providing access numbers and securing the voucher specimens at MNHN. Finally, special thanks to Philip Miller; Pablo Pita, Leo Venerus and Gastón Pereyra who contributed to improve this manuscript.

\section{References}

Burrows, M. T., Schoeman, D. S., Buckley, L. B., Moore, P., Poloczanska, E. S., Brander, K. M., Brown, C., Bruno, J. F., Duarte, C. M., Halpern, B. S., Holding, J., Kappel, C. V., Kiessling, W., O’Connor, M. I., Pandolfi, J. M., Parmesan, C., Schwing, F. B., Sydeman, W. J., Richardson, A. J. 2011. The pace of shifting climate in marine and terrestrial ecosystems. Science, 334: 652-655. https://doi: 10.1126/science.1210288.

Devincenzi, G.J. 1926. Peces del Uruguay. Anales del Museo de Historia Natural de Montevideo, Serie 2, T. I., pp 97-293 \& T. II, pp. 
https://www.mnhn.gub.uy/innovaportal/file/81 454/1/anales-1926-1928-serie-2-numero-2--devincenzi---peces-del-uruguay-notascomplementarias.pdf

De Wysiecki, A. M., Bruno, I., Carvalho-Filho, A. \& Milessi, A. C. 2018. First documented records of tropical morays (Muraenidae) in Argentina and Uruguay. Pan-American Journal of Aquatic Sciences, 13(3): 254-259. https://panamjas.org/pdf_artigos/PANAMJAS _13(3)_254-259.pdf

Franco, B. C., Palma, E. D., Combes, V., Acha, E. M., Saraceno, M. 2018. Modeling the offshore export of Subantarctic Shelf Waters from the Patagonian shelf. Journal of Geophysical Research: Oceans, 123: 4491-4502. https://doi.org/10.1029/2018JC013824

Franco, B. C., Defeo, O., Piola, A. R., Barreiro, M., Yang, H., Ortega, L., Gianelli, I., Castello, J. P., Vera, C., Buratti, C., Pájaro, M., Pezzi, L. P. \& Möller, O. 2020. Climate change impacts on the atmospheric circulation, ocean, and fisheries in the southwest South Atlantic Ocean: a review. Climatic Change, 1-19. https:/doi: 10.1007/s10584-020-02783-6

Gianelli, I., Ortega, L., Marín, Y., Piola, A. R. \& Defeo, O. 2019. Evidence of ocean warming in Uruguay's fisheries landings: the mean temperature of the catch approach. Marine Ecology Progress Series, 625: 115-125. https://doi.org/10.3354/meps13035

Gordon, A. L. 1989. Brazil-Malvinas Confluence1984. Deep-Sea Research, 36: 359-384. https://doi.org/10.1016/0198-0149(89)900423

ICES. 2020. Working Group on Recreational Fisheries Surveys (WGRFS; outputs from 2019 meeting). ICES Scientific Reports. 2:1. 78 pp. https://doi.org/10.17895/ices.pub.5744

Irigoyen, A. J., Galván, D. E., \& Venerus, L. A. 2005. Occurrence of dusky grouper Epinephelus marginatus (Lowe, 1834) in gulfs of northern Patagonia, Argentina. Journal of Fish Biology, 67: 1741-1745. https://doi.org/10.1111/j.10958649.2005.00866.x

Laporta, M., Fabiano, G., Silveira, S., Pereyra, M. I, Scarabino, F. \& Santana, O. 2018. Peces e invertebrados capturados en las pesquerías artesanales oceánicas de enmalle y palangre de fondo de Uruguay. Revista del Frente Marítimo, Vol. 25: 325-348. http://ctmfm.org/
upload/archivoRevista/ctmfm_vol25153668188585.pdf

Lehtiniemi, M., Outinen, O. \& Puntila-Dodd, R. 2020. Citizen science provides added value in the monitoring for coastal non-indigenous species. Journal of Environmental Management, Vol. 267: 110608. https://doi.org/10.1016/j.jenvman.2020.11060 8

Leoni, V., González, S., Ortega, L., Scarabino, F., Failla-Siquier, G., Dutra, A., Rubio, L., Abreu, M., Serra, W., Alonzo Campi, A. G., Stampar, S. N. \& Morandini, A. C. 2016. Tamoya haplonema (Cnidaria: Cubozoa) from Uruguayan and adjacent waters: oceanographic context of new and historical findings. Marine Biodiversity Records, 9: 92. https://doi.org/10.1186/s41200-016-00937

Lewandowski, E., \& Specht, H. 2015. Influence of volunteer and project characteristics on data quality of biological surveys: data quality of volunteer surveys. Conservation Biology, 29: 713-723. https://doi.org/10.1111/cobi.12481

Loureiro, M., Serra, W. S. \& Scarabino, F. 2016. Colecciones Ictiológicas del Uruguay: Pasado y Presente. In: Del Moral, L. F., Ramírez, A. J., Martínez, J. A., González A. P. \& Franco, J. (Eds.) Colecciones ictiológicas de Latinoamérica. Tlalnepantla, Edo. de México: Facultad de Estudios Superiores Iztacala, Universidad Nacional Autónoma de México, 586 pp. https://www.researchgate.net/ profile/Luis_Fernando_Flores/publication/ 328518387_Colecciones_ictiologicas_de_Lati noamerica/links/5bd25d5e92851c6b278f2d9e/ Colecciones-ictiologicas-de-

Latinoamerica.pdf

Manta, G., de Mello, S., Trinchin, R., Badagian, J., \& Barreiro, M. 2018. The 2017 record marine heatwave in the Southwestern Atlantic shelf. Geophysical Research Letters, 45: 12.44912.456.

https://doi.org/10.1029/2018GL081070

Marceniuk, A. P., Caires, R. A., Machado, L., Dantas Cerqueira, N. N. C., M. de S. Serra, R. R. \& Oliveira, R. 2019. Redescription of Orthopristis ruber and Orthopristis scapularis (Haemulidae: Perciformes), with a hybridization zone off the Atlantic coast of South America. Zootaxa, 4576 (1): 109-126. https://doi.org/10.11646/zootaxa.4576.1.5 
Martínez, A., Méndez, S., Fabre, A. \& Ortega, L. 2017. Intensificación de floraciones de dinoflagelados marinos en Uruguay. INNOTEC, $13: \quad 19 \quad-\quad 25$ https://doi.org/10.26461/13.02

Menni, R. C., Ringuelet, R. A. \& Aramburu, R. H. 1984. Peces marinos de la Argentina y Uruguay. Reseña histórica, Clave de familias, géneros y especies. Catálogo crítico. Ed. Hemisferio Sur, Buenos Aires, 359

pp. https://core.ac.uk/download/pdf/301080665.p df

Nion, H., Ríos, C. \& Meneses, P. 2016. Peces del Uruguay. Segunda Edición corregida y ampliada. DINARA, Uruguay. 174 pp. https://asociacionoceanograficauruguaya.files. wordpress.com/2018/08/peces-de-uruguay21.pdf

NOAA. 2020a. National Centers for Environmental Information, State of the Climate: Global Climate Report for March 2018 (06/21/2020). Retrieved from https://www.ncdc.noaa.gov/sotc/global/20180 3.

NOAA. 2020b. National Centers for Environmental Information, State of the Climate: Global Climate Report for April 2018 (06/21/2020). Retrieved from https://www.ncdc.noaa.gov/sotc/global/20180 4.

NOAA. 2020c. National Centers for Environmental Information, State of the Climate: Global Climate Report for February 2019 (06/21/2020). Retrieved from https://www.ncdc.noaa.gov/sotc/global/20190 2.

NOAA. 2020d. National Centers for Environmental Information, State of the Climate: Global Climate Report for May (06/21/2020). Retrieved from https://www.ncdc.noaa.gov/sotc/global/20190 5.

NOAA. 2020e. National Centers for Environmental Information, State of the Climate: Global Climate Report for January 2020 (06/21/2020). Retrieved from https://www.ncdc.noaa.gov/sotc/global/20200 1.

NOAA. 2020f. National Centers for Environmental Information, State of the Climate: Global Climate Report for April 2020 (06/21/2020). Retrieved from https://www.ncdc.noaa.gov/sotc/global/20200 4.

Ortega, L., Castilla, J. C., Espino, M., Yamashiro, C. \& Defeo, O. 2012. Effects of fishing, market price, and climate on two South American clam species. Marine Ecology Progress Series, 469: 71-85. https://doi.org/10.3354/meps10016

Ortega, L., Celentano, E., Delgado, E. \& Defeo, O. 2016. Climate change influences on abundance, individual size and body abnormalities in a sandy beach clam. Marine Ecology Progress Series, 545: 203-213. https://doi.org/10.3354/meps11643

Pauly, D. \& Cheung, W. W. L. 2018. Sound physiological knowledge and principles in modeling shrinking of fishes under climate change. Global Change Biology, 24:e15-e26. https://doi.org/10.1111/gcb.13831

Pereyra I., Mas, F., Scarabino, F. Laporta, M. Silveira, S., Martínez \& Fabiano, G. 2019. Excepcionales y olvidados: los registros más australes del género Rhizoprionodon (Chondrichthyes: Carcharhinidae) en el Atlántico sudoccidental. Libro de Resúmenes del Primer Congreso Latinoamericano de Tiburones, Rayas y Quimeras y VIII Simposium Nacional de Tiburones y Rayas. p.146.

https://www.researchgate.net/profile/Edgar_B ecerril-Garcia/publication/

332232911_Libro_de_Resumenes_del_Primer _Congreso_Latinoamericano_de_Tiburones_

Rayas_y_Quimeras_y_VIII_Simposium_Naci onal_de_Tiburones_y_Rayas/links/ 5ca7a067a6fdcca26d012943/Libro-deResumenes-del-Primer-CongresoLatinoamericano-de-Tiburones-Rayas-yQuimeras-y-VIII-Simposium-Nacional-deTiburones-y-Rayas.pdf

Piola, A. R., Palma, E. D., Bianchi, A. A., Castro, B. M., Dottori, M., Guerrero, R. A., Marrari, M., Matano, R. P., Möller, O. O., Saraceno, Jr. M. 2018. Physical Oceanography of the SW Atlantic Shelf: A Review. Pp 37-56. In: Hoffmeyer, M., Sabatini, M., Brandini, F., Calliari, D., Santinelli, N. (Eds) Plankton Ecology of the Southwestern Atlantic. From the Subtropical to the Subantarctic Realm. Springer, Cham, Switzerland, 592 p. https://doi.org/10.1007/978-3-319-77869-3.

Pita, P., García-Allut, A., Villasante, S. 2018. The role of marine stakeholders in the co- 
production of scientific knowledge: lessons from Galicia (NW Spain). Pp 55-65. In: Briand, F. (Ed.) CIESM 2018. Engaging marine scientists and fishers to share knowledge and perceptions - Early lessons. CIESM Workshop Monograph $\mathrm{n}^{\circ} 50$. CIESM Publisher, Paris, Monaco, 218 p. http://www.ciesm.org/online/monographs/Pari s18.html

Pita, P., Antelo, M., Hyder, K., Vingada, J. \& Villasante, S. 2020. The use of recreational fishers' ecological knowledge to assess the conservation status of marine ecosystems. Frontiers in Marine Science, 7. https://doi.org/10.3389/fmars.2020.00242

Poloczanska, E. S., Brown, C. J., Sydeman, W. J., Kiessling, W., Schoeman, D. S., Moore, P. J., Bruno, J. F, Buckley, L. B., Burrows, M. T., Duarte, C. M., Halpern, B. S., Holding, J., Kappel, C. V., O’Connor, M. I, Pandolfi, J. M., Parmesan, C., Schwing, F., Thompson, S. A. \& Richardson, A. J. 2013. Global imprint of climate change on marine life. Nature Climate Change, 3: 919-925. https://doi:10.1038/nclimate1958

Poloczanska, E. S., Burrows, M. T., Brown, C. J., García-Molinos, J., Halpern, B. S., HoeghGuldberg,O., Kappel, C. V., Moore P. J., Richardson, A. J., Schoeman, D. S. \& Sydeman, W. J. 2016. Responses of marine organisms to climate change across oceans. Frontiers in Marine Science, 3:62. https://doi: 10.3389/fmars.2016.00062

Possamai, B., Vieira, J. P., Grimm, A. M., \& Garcia, A. M. 2018. Temporal variability (1997-2015) of trophic fish guilds and its relationships with El Niño events in a subtropical estuary. Estuarine, Coastal and Shelf Science, 202, 145-154.

https://doi.org/10.1016/j.ecss.2017.12.019
Scarabino, F., Zelaya, D. Orensanz, J. M. (Lobo), Ortega, L., Defeo, O., Schwindt, E., Carranza, A., Zaffaroni, J. C., Martínez, G., Scarabino, V. \& García-Rodríguez, F. 2016. Cold, warm, temperate and brackish: Bivalve biodiversity in a complex oceanographic scenario (Uruguay, southwestern Atlantic). American Malacological Bulletin, 31 (2): 284-30. https://doi.org/10.4003/006.033.0219

Tiralongo, F., Crocetta, F., Riginella, E., Lillobd, A. O., Tondob, E., Macalibe, A., Mancinibf, E., Russob, F., Cocobg, S., Paolilloh, G. \& Azzurroci, E. 2020. Snapshot of rare, exotic and overlooked fish species in the Italian seas: A citizen science survey, Journal of Sea Research, 101930. https://doi.org/10.1016/j.seares.2020.101930.

Venturelli, P. A., Hyder, K. \& Skov, C. 2016. Angler apps as a source of recreational fisheries data: opportunities, challenges and proposed standards. Fish and Fisheries, 18 (3): 578595. https://doi.org/10.1111/faf.12189

Vianna, M. \& Verani, J. R. 2002. Biologia populacional de Orthopristis ruber (Teleostei, Haemulidae) espécie acompanhante da pesca de arrasto do camarão-rosa, no sudeste brasiliero. Atlântica, 23(1): 27-36. https://doi.org/10.5088/ATL.2002.4

Vieira, J. P., Garcia, A. M. \& Lemos, V. M. 2018. Species composition and abundance patterns of fish assemblages at shallow waters of Patos Lagoon estuary. v1.8. Sistema de Informação sobre a Biodiversidade Brasileira - $\quad$ SiBBr. Dataset/Samplingevent.https://ipt.sibbr.gov.br/ peld/resource?

r=species_composition_and_abundance_patte rns_of_fish_assemblages_at_shallow_waters_ of_patos_lagoon_estuary\&v=1.8 https:// doi.org/10.15468/kci8zb

Received: Jannuary 2021

Accepted: April 2021

Published: November 2021 